\title{
The influence of fertilization and environment on some nutritionally important quality criteria in vegetables - a review of research in the Nordic countries
}

\begin{abstract}
AINO-MAIJA EVERS
EVERS, A.-M. 1994. The influence of fertilization and environment on some nutritionally important quality criteria in vegetables - a review of research in the Nordic countries. Agricultural Science in Finland 3: 177-188. (Agricultural Research Centre of Finland, Institute of Horticulture, FIN-21500 Piikkiö, Finland. Present address: Department of Plant Production, P.O. Box 27, FIN-00014 University of Helsinki, Finland.)

To understand the phenomena caused by nutrient applications on the quality of vegetables, some research has been done in Finland and in Scandinavia during the last decades. Purpose of this review is to evaluate this data against the information available on genetic and environmental factors.

Genotype and light intensity highly affect the vitamin $\mathrm{C}$ content of plants. Optimal nitrogen level has a small effect, but excess of nitrogen decreases vitamin $\mathrm{C}$ content. Genotype, developmental stage of the plant, adequate photosynthesis, vigorous growth and relatively high temperature increase the carotene content of carrots. The effects of fertilization on the carotene content of plants have been contradictory and warrants more research. No research results could be found of the effects of fertilization or growing practices on the vitamin B content even though vegetables are an important source of vitamin B in diets. Increasing nitrogen fertilization, genotype, low light intensity, low temperature and drought increase the nitrate content of vegetables, but the levels are low in vegetables grown in the Nordic countries, except in lettuce grown under glass with the aid of lights during the dark season. The effect of fertilization on the sugar content is small, and the effect on dietary fibre warrants further study.
\end{abstract}

Key words: nutrient, growing practice, climate, dry matter, vitamin, carotene, sugar, fibre, nitrate

\section{Introduction}

The marketable yield and quality of vegetables are influenced by genotype, environment, growing practice, harvest, storage and marketing. Also fertilization can be manipulated by the grower and thus it is important to understand the phenomena caused by nutrient applications. The amount, type and form of nutrients, and the method of nutrient application will influence plant growth patterns, yield, maturation, nutritional value and post harvest physiology. The trend in agriculture and horticulture is towards 'sustainable' farming which means more economic fertilizer application for ecological and economic reasons. In that context it is important to understand the effects of nutrients and nutrient amounts on the marketable yield and nutritional quality of vegetables.

During the last decades, some research has been 
conducted in the Nordic countries on fertilization and quality of vegetables (e.g. Balvoll 1969, ROSENFELD 1978, NiLSSON 1979, LEHTINEN 1984, NygaARd Sørensen 1984, 1988, Aura 1985, Evers 1989a, b, c, d, e, Balvoll 1992). In the Nordic countries, the growing conditions are extreme compared to Central and Southern Europe. The growing period is short, summer days are long and temperatures are relatively low. These environmental factors affect the quality of vegetables (ÅBerg 1946, Dragland 1969, HÅrdH and HÅrdH 1972, BAlVOll et al. 1975, HÅrdH et al. 1977) and they must be taken into account when interpreting the results of experiments on fertilization. The purpose of this review is to assemble and analyse this data to provide a basis for modifying agronomic practice in Nordic countries towards a more 'sustainable' system without impairing nutritonal quality.

\section{Vitamin C / ascorbic acid in plants}

Genotype has a very strong influence on the vitamin $\mathrm{C}$ content of plants and thus plant species differ greatly in their vitamin $\mathrm{C}$ composition. Examples of high contents $(\mathrm{mg} / 100 \mathrm{~g}$ fresh edible matter) are rose hip (840), sea buckthorn berry (200), parsley (190), black currant (181), horse radish (152), sweet pepper (144), kale (110), brussels sprout (85), broccoli (83) and cauliflower (73). Some plant species are quite important sources of vitamin $\mathrm{C}$ because of the high consumption in Finnish diets. Examples of these are strawberry (68), white cabbage (44), chinese leaves (27), tomato (17), potato (11) and cucumber (8). Root crops often have a low vitamin $\mathrm{C}$ content $(\mathrm{mg} / 100 \mathrm{~g}$ fresh edible matter), e.g. celeriac (11), beet root (8) and carrot (5) (Kansaneläkelaitos 1993).

Light is the most important exogenous factor influencing the ascorbic acid content of vegetables, fruits and berries (ÅBERG 1946, MURNEEK et al. 1954, Brown 1955, MAPSON 1955). ÅBERG (1949) in Sweden showed that the ascorbic acid content decreases quickly when a plant leaf is shaded but increases again when the plant leaf gets light. At low light intensities the increase of ascorbic acid content is linear to the increase of light intensity, and increased daylength has the same effect (ÅBERG 1946). No other Scandinavian or Finnish study was found on this subject, but in other countries it has been shown clearly that light increases the ascorbic acid content in apple (JohANSSON 1939, KesSLer 1939, MuRNEEK and WITTWER 1948, MURNEEK et al. 1954), strawberry (SCHUPhan 1942, HANSEN and Waldo 1944, EZELL et al. 1947, RoBinson 1949) and tomato (KASKI et al. 1944, Brown 1955, HAMNER et al. 1945, McCollum 1946, Somers et al. 1950, MURNEEK et al. 1954). These studies showed that it is important that the apple, strawberry and tomato fruit itself is exposed to light, not only the plant leaves, and the amount of light close to the harvest period is especially important for high ascorbic acid content.

The correlation between temperature and ascorbic acid content of the plant is negative ( $\AA$ BERG 1946, Rosenfeld 1975, 1979). Thus low temperatures increase the ascorbic acid content in plants, probably due to lower carbohydrate consumption in plant metabolism. Plant dry matter content correlatied positively with ascorbic acid content in all eight plant species studied by RosENFELD (1975, 1979).

Many studies have been conducted in the Nordic countries on the effect of latitude on the quality of plants, but no obvious effect of latitude have be seen (HÅRDH 1964, 1975, KUUSI 1965, NilsSON 1969, Dragland 1969, HÅRDH and HÅRDH 1972). Most of the differences in quality were assumed to be due to the developmental stage of the plants studied, and the ascorbic acid content is most likely affected by the light conditions close to the harvest period. LINDEN (1989) suggests that due to long summer days and relatively low temperatures ascorbic acid content is the quality criterion which is most likely to be affected positively by the northern conditions.

\section{The effect of fertilization on the vitamin C / ascorbic acid content}

There are only few studies on the effect of fertilization on the ascorbic acid content of vegetables, 
fruits and berries in the Finnish and Scandinavian literature. In his review RoSENFELD (1978) concludes that both structural and metabolic changes affect ascorbic acid levels. Intensive use of carbohydrates in protein synthesis may compete with ascorbic acid production leading to decreased ascorbic acid content in plants. The competition seems to be absent in high light intensities. A high amount of nitrogen fertilizer results in a leaf structure similar to that in plants grown in shadow. The effect of irrigation is clear according to ROSENFELD (1978): drought increases and irrigation decreases the ascorbic acid content in plants.

NILSSON (1979) studied the effects of organic and mineral fertilizers at normal and half doses on the yield, storability and chemical composition of carrot, white cabbage and leek. Neither fertilizer nor fertilizer level affected the vitamin $\mathrm{C}$ content in freshly harvested or stored cabbage and leek. The different fertilizers had no influence on the yield of carrots and leeks, but organic fertilizers decreased the yield of cabbage significantly the first year but not the second year. Half the amount of fertilizer resulted in significantly lower yields of cabbage and leek for both years, but had no effects on the yield of carrots.

In his discussion NiLsson (1979) states that potassium is the nutrient that affects the vitamin $\mathrm{C}$ content in vegetables the most, because potassium is important in the carbohydrate synthesis. The lack of potassium decreases photosynthesis and increases respiration (ref. MEngel 1972). NILSSON (1979) further claims that the N/K relationship is important. Low potassium fertilization combined with increasing N/K decreases the vitamin $\mathrm{C}$ content. In such cases the fresh yield increases, but the dry matter content decreases. Thus organic and mineral fertilizers do not affect the vitamin $\mathrm{C}$ content if one uses $\mathrm{N} / \mathrm{K}$ in the right proportion. According to NiLsson (1979), the vitamin $\mathrm{C}$ content is not influenced by any other macronutrient if there is no deficiency.

The dry matter and vitamin $\mathrm{C}$ contents were higher in biodynamically cultivated potatoes than in conventionally cultivated potatoes (PETTERSSON 1982). This result has been criticised, because Pettersson used $120 \mathrm{~kg} \mathrm{~N} / \mathrm{ha}$, which is too much for conventionally grown potatoes. Biodynamically grown potatoes did not suffer from excess nitrogen, because organic fertilizers release their nutrients slowly over a period of years.

In the study of NYGAARD SøRENSEN (1988), increasing nitrogen amount decreased the vitamin $\mathrm{C}$ content in cabbage. The reduction is assumed to be due to the bigger outer leaves which shade the inner leaves and the head. Increasing potassium amount increased the vitamin $\mathrm{C}$ content in white cabbage. There was a clear positive correlation between vitamin $\mathrm{C}$ and dry matter content.

\section{Carotene in plants}

Carotenoids are tetraterpenes of the isoprenoid group (GABELMAN 1974). Carotenoids include carotenes and xanthophylls, and some carotenes are important for human nutrition because they are precursors of vitamin A (DEVLIN 1975). Genotype, plant species and variety, are important factors for plant carotene content (SIMON et al. 1982, SimON and WolfF 1987, HeINONEN 1990, Kansaneläkelaitos 1993). Examples of high $\beta$ carotene content $(\mu \mathrm{g} / 100 \mathrm{~g}$ fresh edible matter) are carrot (7600), parsley (5600), spinach (3300), celery (2900), red sweet pepper (2900), kale (2150), broccoli and leek (1000), lettuce (980) and tomato (660) (Kansaneläkelaitos 1993).

Carrots grown in European coutries have usually been selected for their root colour which is caused by the presence of $\beta$ - and $\alpha$-carotene. Because carrot is widely consumed it has become the major source of $\beta$-carotene in Western European diets. For these reasons the factors affecting the carotenoid content of carrot have been the subject of much research. These studies confirm that the carotene content of carrots is influenced by genotype (GABelman 1974, SimON and WolfF 1987), environment (BARNES 1936, BANGA et al. 1955, HabBen 1972, SimON et al. 1982, SimON and WOLFF 1987) and by the size and age of carrot (BARNES 1936, BANGA et al. 1963, BANGA and BRuYn 1964, Habben 1972, Phan and Hsu 1973). 
BANGA and BRUYN (1964) summarise that in carrot the enlargement of the root and maturation proceed simultaneously. Different conditions may favour one activity more than the other. With increasing root size the carotenoid concentration gradually increases up to a certain maximum. This is caused by the increase in the carotenoid content in the individual cells of the maturing tissue, and the increase in the ripe upper part of the root. The carotenoid contents of carrot roots should therefore be determinend in relation to the size of the root. The carotenoid content depends primarily on adequate photosynthesis. If the roots are grown in a well-drained soil of good structure, there are two types of growing conditions which may further modify the carotenoid content in relation to root weight. These are the factors that control the growth rate (plant density, soil moisture content, nutrient supply) and temperature. High temperature favours maturation, whereas low temperature favours primary vegetative growth. Thus adequate photosynthesis (light), vigorous growth (plant density, soil moisture, nutrient supply) and relatively high temperature are the exogenous factors that increase the $\beta$-carotene content in carrots. BANGA et al. (1955), BANGA and BRUYN $(1964,1968)$ have found that low temperatures $\left(+8^{\circ} \mathrm{C}\right)$ delay root growth and cause low carotenoid content. At high temperatures $\left(17-23^{\circ} \mathrm{C}\right)$, protein synthesis decreases and more photosynthases become available for carotenoid synthesis. Both BARNES (1936) and BANGA et al. (1955) reported that high temperature favours carotene synthesis. Evers (1989b) showed in Finland that the carotenoid content was higher in a warm summer than in a cold and rainy summer.

Carrots produced in Southern Sweden (LAMBRECHT and SVENSSON 1950, NILSSON and HiNTZE 1952), in Southern Norway (BALvoll et al. 1975) and in Southern-Finland (HÅRDH 1975, HÅRDH et al. 1977) contain more carotene than carrots produced in the northern parts of the countries. Researchers assume this to be due to the fact that carrots in the north have not reached the same developmental stage and, consequently contain less carotenoids.

\section{The effects of fertilization on carotene content}

Only three studies from Scandinavia and one from Finland were found on the effect of fertilization on the carotene content of vegetables. Increased nitrogen fertilization increased the carotene content in spinach (BaLVoLl 1969). Organic and mineral fertilizers at normal or half rates did not affect the carotene contents of carrot either at harvest or after a storage period (NILSSON 1979). NILSSON claims that nitrogen is not a limiting factor and that it was the exceptional warmth in the summers of 1975 and 1976 that determined the carotene levels. The carotene levels were very high in that study $(18-20 \mathrm{mg} / 100 \mathrm{~g}$ fresh weight $\alpha+\beta$-carotene) analysed spectrophotometrically. Usually the carotene contents are lower: 6.19.3 (NygaARd Sørensen 1988), 3.4-6.4 (Evers $1989 \mathrm{~b}$ ), $7.3-15.1 \mathrm{mg} / 100 \mathrm{~g}$ fresh weight (HEINONEN 1990).

Increasing nitrogen and potassium fertilization both increased the carotene content in carrots (NygaARd SøREnSEn 1988). Nitrogen increased the carotene content even at supra optimal levels, but potassium increased the carotene content at optimal level only.

EVERS (1989b) studied the effects of different fertilization practices. The best application methods increased the carotene content in two climatically different years. In 1985, which was climatically an unfavourable year, placement fertilization increased the carotene content by $35 \%$, NPK fertirrigation with basic fertilization by $28 \%$, and PK placement with three nitrogen fertigations by $44 \%$ compared to no fertilization. In 1986 , which was climatically a favourable year, the increases were respectively $9 \%, 9 \%$ and $10 \%$. Thus placement of PK fertilizer is profitable especially in poor weather conditions. In the unfavourable year 1985 the placement of PK fertilizer showed a tendency $(p=0.1)$ to increase the carotene content in carrots compared to other fertilization practices, but no other significant differences were found between fertilizer application methods. The surplus nitrogen did not affect the carotene content as compared to the average of other fertilization treatments, where the $\mathrm{N}$ amount 
applied was thought to be optimal on the basis of the yield. Thus Evers (1989b) could find no indication that the optimal or surplus nitrogen amount or application method would have any further effect.

The variation in the carotene content of carrot mainly depends on the genotype (GABELMAN 1974) and the climate (SIMON et al. 1982). Also EVERS (1989b) observed a clear difference in the mean carotene content between the two years. The average carotene content for all treatments was $41.2 \%$ higher in the favourable year 1986 than in the cold and rainy year 1985. There is general agreement in the literature that the carotenoid content of carrots increases with maturation of the plant (BANGA et al. 1963, PHAN and Hsu 1973, FritZ and HabBEn 1975, Evers 1989b).

The carotene content in carrots correlates positively with the dry matter content and high shoot/ root ratio (BANGA and BRUYN 1964, EVERS 1989e). BANGA and BRUYN (1964) summarise that high dry matter content can be regarded as an indicator of intensive photosynthesis, and carotene content in carrots is dependent on the intensity of photosynthesis and the size of the foliage used for photosynthesis.

\section{Vitamin B in plants}

The vitamin B complex comprises vitamin B1/ thiamine, vitamin B2/ riboflavin, niacin (nicotinic acid and nicotinamide ), vitamin B6/pyridoxine, vitamin B12, folic acid, pantothenic acid and biotin. Vegetables are an important source of vitamin B in Danish diets: $19 \%$ of vitamin B1, 9\% of vitamin B2, $14 \%$ of vitamin B6, $29 \%$ of folic acid and $13 \%$ of niacin are obtained from vegetables. Fruits and berries are not so important for only $2-6 \%$ of the total vitamin B intake is obtained from fruits and berries in Denmark (Levnedsmiddelstyrelsen 1990). No studies have been conducted in the Nordic countries concerning the influence of environment, fertilization and growing practice on the vitamin B contents of vegetables. Vitamin B levels are relatively high in pea (both immature and dry seeds), parsley, spinach, Brussels sprout, bean (both immature pods and dry seeds), broccoli, lettuce, kale and leek, and higher than for instance in whole wheat flour or beef. Potato, carrot and tomato contain moderate quantities of vitamin B.

\section{The effects of fertilization on vitamin B}

No research results on the influence of fertilization on the vitamin B content of vegetables, fruits and berries could be found in Scandinavian and Finnish literature. Because vegetables are an important source of vitamin B in human diets, the effects of growing conditions should be studied.

\section{Nitrates in plants}

Nitrate $\left(\mathrm{NO}_{3}^{-}\right)$is undesirable in vegetables, because it may be reduced to nitrite $\left(\mathrm{NO}_{2}^{-}\right)$which is hazardous to babies and may be involved in the development of gastro-intestinal cancer. Nitrate accumulation in plants is attributed mainly to genotype, light intensity, daylength, temperature, soil moisture content and nitrogen fertilization. Wide fluctuation has been observed also during a 24-hour period (MAYNARD et al. 1976, CORRÉ and BREIMER 1979). Nitrate contents exceeding $2500 \mathrm{mg} \mathrm{NO}_{3} / \mathrm{kg}$ fresh matter have been observed in celery, spinach, beetroot, radish and lettuce. In turnip, cabbage, parsley leaves, celeriac, leek and rhubarb, the nitrate contents usually range from 1000 to $2500 \mathrm{mg} \mathrm{NO} / \mathrm{kg}$ fresh matter (CORRÉ and BREIMER 1979). Butterhead lettuce varieties differ considerably in their nitrate content, whereas spinach varieties differed only sightly (BEHR 1988). It is well documented that high light intensity, high total radiation and long days decrease the nitrate content of vegetables. This is an important contributory factor for low nitrate content in spring and summer, and higher content in autumn and winter. The effect of temperature is complex and interrelated with light, soil moisture and nitrogen supply (MAYNARD et al. 1976). 
Table 1. The effects of plant species, years and $\mathrm{N}$ fertilization on the nitrate- $\mathrm{N}$ content of carrot and red beet (VUORINEN and TAKALA 1987).

\begin{tabular}{|c|c|c|c|c|c|c|}
\hline \multirow{3}{*}{ Year } & \multicolumn{6}{|c|}{ Nitrate- $\mathrm{N}$ content ${ }_{\mathrm{NO}_{3}}-\mathrm{N} \mathrm{mg} / \mathrm{kg}$ fresh matter } \\
\hline & \multicolumn{3}{|c|}{$\begin{array}{l}\text { Carrot } \\
\mathrm{kg} \mathrm{N} / \mathrm{ha}\end{array}$} & \multicolumn{3}{|c|}{$\begin{array}{l}\text { Red beet } \\
\mathrm{kg} \mathrm{N} / \mathrm{ha}\end{array}$} \\
\hline & 60 & 120 & 180 & 60 & 120 & 180 \\
\hline 1980 & 16.8 & 46.6 & 55.3 & 205.6 & 392.9 & 438.3 \\
\hline 1981 & 5.6 & 11.7 & 21.7 & 24.2 & 117.3 & 155.7 \\
\hline 1982 & 27.2 & 60.0 & 87.6 & 43.0 & 201.9 & 284.5 \\
\hline 1983 & 12.1 & 21.1 & 32.9 & 28.5 & 92.9 & 169.7 \\
\hline
\end{tabular}

\section{The effect of fertilization on the nitrate content}

The nitrate content of vegetables increases with increasing fertilizer nitrogen amount, and plenty of Scandinavian and Finnish literature can be found on this subject (EPPENDORFER 1978, NILSSON 1979, LehtiNEN 1984, AURA 1985, Bodin 1988, NygaARD SørEnSEN 1988, Evers 1989c, JOKINEN and TAHVONEN 1991, ANDERSEN and NiELSEN 1992, SALO 1992). Also genotype, light intensity, daylength, temperature, and soil moisture content clearly affect the nitrate content of vegetables (MAYNARD et al. 1976, CORRÉ and BREIMER 1979). Therefore research results should always be interpreted in the whole context. The research results in Table 1 (VUORINEN and TAKALA 1987) are very illustrative. The greatest variation can be found between plant species; the variation due to climatic differences in different years and the variation caused by increasing nitrogen fertilization are considerable but smaller than variation between plant species.

Even though the effect of increasing nitrogen amount is evident, the consequence is surprising. The absolute nitrate contents in Finnish and Scandinavian vegetables (Table 2) are clearly below the limit values applied in the other European countries although in fertilization experiments high levels of nitrogen have also been used. Only in lettuce grown in greenhouses, the concentrations are close to the limit values.

\section{Carbohydrates, sugars and dietary fibre}

Plant dry matter mainly consists of carbohydrates i.e. sugars, starch and fibre. All plants contain sugars and fibre, but nuts, bananas, potatoes, maize and dried peas, beans and lentils contain also starch. Carbohydrates make up $50.6 \%$ of the total energy intake in Finnish diets, and this is in accordance with the recommended dietary allowances (Kansaneläkelaitos 1993). Vegetables, root crops and leguminous crops make up $11 \%$ of the total carbohydrate intake, and their amount in diets should be increased. These crops are important sources of fibre, they make up $19 \%$ of the total fibre intake in Finland (KLEEMOLA et al. 1994).

\section{The effect of fertilization on the sugar and fibre contents}

The effect of fertilization on the sugar content of vegetables has been small in the experiments made in the Nordic countries (Dragland 1978, NiLSSON 1979, AURA 1985, VUORINEN and TAKAlA 1987, NygaARD Sørensen 1988, TAKala et al. 1988, EVERS 1989d), and often the variation between plant species and years has been much greater than the differences between fertilization treatments (AURA 1985, VUORINEN and TAKALA 1987, TAKAlA et al. 1988, Evers 1989d).

Increased nitrogen level decreased the total sugar content in carrot, red beet, white cabbage and 
Table 2. Vegetable nitrate contents in fertilizer experiments conducted in the Nordic countries in 19781992. The results are both in units given in the original papers and in $\mathrm{mg} \mathrm{NO}_{3} / \mathrm{kg}$ fresh matter.

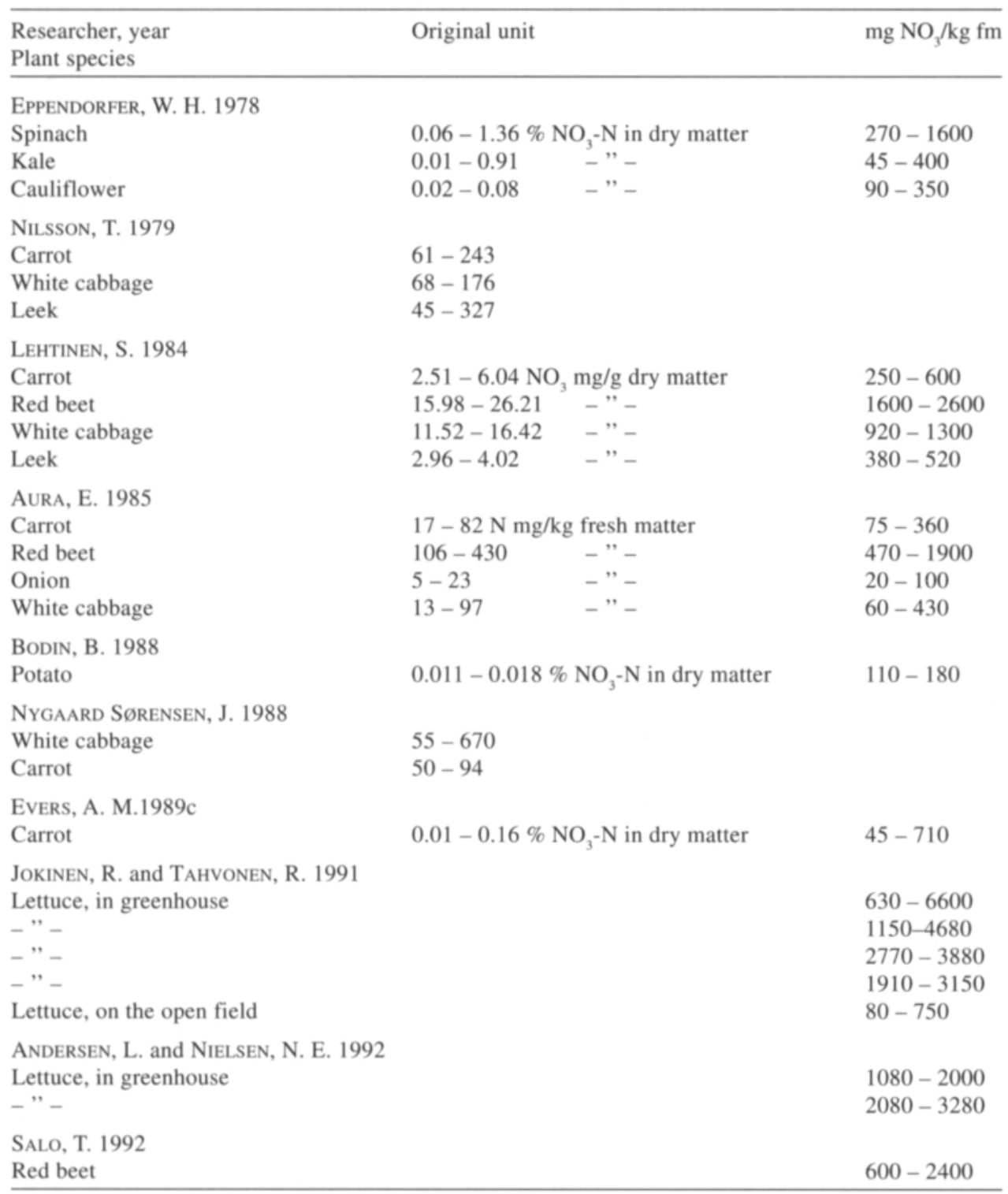

cauliflower in the experiments conducted in Piikkiö in 1978-1983. Single fertilizer application at the begining of the growing season yielded higher sugar contents than split applications (three applications during the growing season) in red beet, white cabbage, cauliflower and celeri- ac. However, the variations between plant species and between years were greater than the variations between fertilizer treatments. The results of these experiments show also a tendency for the sugar content to be higher when the yield remained lower. This could be seen in car- 
rot, red beet and white cabbage on clay soil, and in cauliflower, but early summer cabbage and celeriac did not show any such tendency (LEHTINEN 1984).

Increasing nitrogen fertilizer amount decreased the sugar content in carrot (DRAGLAND 1978), red beet (AURA 1985, VUORINEN and TAKALA 1987) and in white cabbage (NYGAARD SøRENSEN 1988). On the other hand, AURA (1985) found no effect on the sugar content in carrot, white cabbage and onion, and NyGaARd SøRENSEN (1988) observed increased nitrogen amount to increase the sugar content in carrot. Broadcast, placement and split application did not affect the sugar content of carrot in Evers' (1989d) study.

Both Nilsson (1979) and TAKAlA et al. (1988) have compared the effects of organic and inorganic fertilizers on the yield and quality of vegetables. Neither the type of fertilizer nor the amount affected the sugar content of carrot and white cabbage. The different farming systems did not affect the starch content of potato or the sugar content of red beet, but the sugar content of carrot was higher in conventional systems than in biological systems (TAKALA et al. 1988).

The fibre in vegetables is important to human health (VARO et al. 1984), but very few reports can be found of the effects of growing technique on the fibre contents of vegetables, berries and fruits. The increase in fertilizer nitrogen amount increased the fibre content in carrot (NYGAARD SøRENSEN 1988, Evers 1989c). EVERS (1989c) further reports that fertilization and irrigation increased the fibre content in carrot, and single application compared to split application also increased the fibre content. On the other hand, increasing nitrogen amount decreased the fibre content in white cabbage (NYGAARD SøRENSEN 1988). PlaAmI et al. (1989) have found that a rainy summer increases the water-insoluble fibre and nitrogen fertilization the water-soluble fibre in rye. Further they found that water-insoluble fibre and total fibre contents correlates positively with protein content. These few research results imply that fertilization and irrigation affect the fibre content and the quality of fibre, thus this item should be studied more closely.

\section{Conclusions}

Genotype has a very strong influence on the vitamin $\mathrm{C}$ content of plants. Light is the most important exogenous factor influencing the vitamin $\mathrm{C}$ content of vegetables, fruits and berries. At low light intensities the increase of vitamin $\mathrm{C}$ is linear to the increase of light intensity, and increased daylength had the same effect. Temperature correlates negatively with the vitamin $\mathrm{C}$ content of plants. At the optimal nitrogen level nitrogen has a small effect on the vitamin $\mathrm{C}$ content of vegetables. If there is enough nitrogen for biomass production and protein synthesis, vitamin $\mathrm{C}$ content is mainly affected by genotype and light intensity. In nitrogen deficiencies the dry matter and vitamin $\mathrm{C}$ contents increase, but simultaneously the yields and protein content are low. Overdose of nitrogen causes a reduction in the vitamin $\mathrm{C}$ content, probably due to the shadowing effect of big leaves or due to the decrease of dry matter content. It is obvious that yield, dry matter content and vitamin $\mathrm{C}$ content are interrelated and they should be considered together. Even sugars and dietary fibre could be considered together with yield, dry matter and vitamin C. More research on this topic should be conducted.

Most of the carotene research has been done with carrot. Genotype has a very strong influence on the carotene content. Carotene content increases with maturing of the plant. Adequate photosynthesis, vigorous growth and relatively high temperature increase the carotene content of carrot. In the the Nordic countries no clear trend can be seen on the effects of fertilization on the carotene content; few studies have been conducted and the results are contradictory. The contradictory nitrogen results may be due to the fact that the genotype, the climate and the developmental stage of the plant highly affect the carotene content of carrot and fertilization has a much smaller effect. More research should be done on the effects of fertilization and other growing practices on the carotene content of vegetables, because carotene is nutritionally very important to humans.

No research results on the effect of fertiliza- 
tion on the vitamin B content of vegetables, fruits and berries have been found in Scandinavian or Finnish literature. Because vegetables are an important source of vitamin B in human diets, the effects of fertilization and growing conditions should be studied.

Increasing nitrogen amount increases the nitrate content in vegetables. Also genotype, low light intensity, short daylength, low temperature and drought increase the nitrate content in vegetables. When comparing the absolute nitrate values of Scandinavian and Finnish fertilization experiments with the limit values applied in other European countries, it can be seen that the nitrate content in vegetables are low even at high nitrogen fertilizer levels. Only in lettuce culture in greenhouses is there a need to find ways to lower the nitrate content in plants at harvest. It is therefore not necessary to pay too much attention to the nitrate content of vegetables in future research.

The effect of fertilization on the sugar content are small. In several studies the effects of plant species and years have been much greater than the effect of fertilization. Most of the available research data shows a tendency that increased nitrogen fertilization slightly decreases the sugar content. The effects of fertilization and irrigation on the fibre content should be studied more closely, because the few results available are interesting and the fibre in vegetables is important to human health.

In summary, fertilization affects but little the vitamin $\mathrm{C}$ and sugar contents. Further research is needed on the yield, dry matter, vitamin C, sugars and fibres as one entity to understand more closely the partitioning of photosynthates. The effects of fertilization and growing practices on the carotene, vitamin B and fibre contents are important topics of research as they are essential factors of a healthy diet. The accumulation of nitrate in the plants is quite well understood, but there is a need to find ways to lower the nitrate content in lettuce grown in greenhouses in the dark season.

Acknowledgements. The author thanks Maj-Lis Aaltonen and the personnel of the library of the Agricultural Research Centre of Finland for providing all the necessary information.

\section{References}

ÅBERG, B. 1946. Effects of light and temperature on the ascorbic acid content of green plants. Kunglige Lantbrukshögskolens Annmelinger 13: 239-273.

- 1949. Changes in the ascorbic acid content of darkened leaves as influenced by temperature, sucrose application and severing from the plant. Physiology Plantarum 2: 164-183.

Andersen, L. \& Nielsen, N. E. 1992. A new cultivation method for the production of vegetables with low content of nitrate. Scientia Horticulturae 49: 167-171.

AurA, E. 1985. Avomaan vihannesten veden ja typen tarve. Maatalouden tutkimuskeskus, Tiedote 7/85. p. 1-61. [Nitrogen and water requirements for carrot, beetroot, onion and cabbage. Communications of Agricultural Research Centre of Finland, Jokioinen.]

BANGA, O. \& BRUYN, J. W. de 1964. Carotenogenesis in carrot roots. Netherlands Journal of Agricultural Science 12: 204-220.

- \& BRUYN, J. W. de 1968. Effect of temperature on the balance between protein synthesis and carotenogenesis in the roots of carrot. Euphytica 17: 168-172.
-, Bruyn, J. W. de, Bennekom, J. L. van \& Keulen, H.A. van 1963. Selection of carrots for carotene content. V. The effect of the soil moisture content. Euphytica 12: 137-146.

- Bruyn, J. W. de \& SMeETS, L. 1955. Selection of carrots for carotene content. II. Subnormal content at low temperature. Euphytica 4: 183-189.

BALVOLL, G. 1969. Verknad av nitrogengjødsling på kjemisk samansetnad og næringsverde hjå grønsakvokstrar. Stensiltrykk 35: 1-9. 6 app.

- 1992. Kvalitet i grønsaker. Verknaden av gjødsling på indre kvalitet. Næringsstoffinnhald og smak hos gulrot. Faginfo 3: 5-32.

-, Apeland, J. \& Auranaune, J. 1975. Kjemisk samansetnad og organoleptisk kvalitet hjå gulrot frå Sör- og Nord-Noreg. Forskning og Försök i Landbruket 27: 327-337.

BARNES, W.C. 1936. Effects of some environmental factors on growth and color of carrots. Cornell University, Agricultural Experimental Station Mem. 186: 1-36. BEHR, U. 1988. Sortenvergleich zum Gehalt an Nitrat und 
anderen qualitätsbestimmenden Inhaltsstoffen in Kopfsalat (Lactuca sativa $\mathrm{L}$. var. capitata $\mathrm{L}$.) und Spinat (Spinacia oleracea L.). Dissertation. Universität Hannover. $149 \mathrm{p}$.

Bodin, B. 1988. Quality of table potatoes. Morphology, content of substances and quality properties at different stages of development and growth of the potato tuber. Crop Production Sci. 2: 1-45.

BRown, G. B. 1955. The ascorbic acid content of tomatoes as related to illumination. Proceedings of American Society of Horticultural Science 65: 342-348.

CorRé, W. J. \& Breimer, T. 1979. Nitrate and nitrite in vegetables. $85 \mathrm{p}$. Wageningen.

Devlin, R. M. 1975. Plant Physiology. 3th ed. D. Van Nostrand Company, New York. 600 p.

Dragland, S. 1969. Vitamin C-innholdet i hodekål og kålrot dyrket i Nord- og Sør-Norge. Meld. Norges Landbr. Højsk. 48: 1-11.

- 1978. Nitrogen- og vassbehov hos gulrot. Forskning og Försök i Landbruket 29: 139-159.

EPPENDORFER, W. H. 1978. Effects of N-fertilization on amino acid composition and nutritive value of spinach, kale, cauliflower and potaoes. Journal of Science in Food and Agriculture 29: 305-311.

EVERS, A. M. 1989a. Effects of different fertilization practices on the growth, yield and dry matter content of carrot. Journal of Agricultural Science in Finland 60: $135-152$.

- 1989b. Effects of different fertilization practices on the carotene content of carrot. Journal of Agricultural Science in Finland 61: 7-14.

- 1989c. Effects of different fertilization practices on the $\mathrm{NO}_{3}-\mathrm{N}, \mathrm{N}, \mathrm{P}, \mathrm{K}, \mathrm{Ca}, \mathrm{Mg}$, ash and dietary fibre contents of carrot. Journal of Agricultural Science in Finland 61: 99-111.

- 1989d. Effects of different fertilization practices on the glucose, fructose, sucrose, taste and texture of carrot. Journal of Agricultural Science in Finland 61: 113122.

- 1989e. The role of fertilization practices in the yield and quality of carrot (Daucus carota L.). Journal of Agricultural Science in Finland 61: 323-359.

Ezell, B. C., Darrow, G. M., Wilcox, M. S. \& ScotT, D.H. 1947. Ascorbic acid content of strawberries. Journal of Food Research 12: 510-526.

FrITZ, D. \& HABBEN, J. 1975. Determination of ripeness of carrot (Daucus carota L.). Acta Horticulturae 52: 231-238.

Gabelman, W. H. 1974. The prospects for genetic engineering to improve nutritional values. In: White, P. \& Selwey, N. (eds.). Nutrition qualities of fresh fruits and vegetables, New York. p. 147-155.

HABBEN, J. 1972. Einfluss von Düngung und Standort auf die Bildung wertgebender Inhaltstoffe in Möhren (Daucus carota L.). Dissertation. Technischen Universität München. $123 \mathrm{p}$.

Hamner, K. C., Bernstein, L. \& Maynard, L. A. 1945. Effects of light intensity, day length, temperature and environmetal factors on the ascorbic acid content of tomatoes. Journal of Nutrition 29: 85-97.

HANSEN, E. \& WALDO, G. F. 1944. Ascorbic acid content of small fruits in relation to genetic and environmental factors. Food Research 9: 453-461.

HÅRDH, J. E. 1964. Mustaherukan C-vitamiinipitoisuuteen vaikuttavista tekijöistä. Maataloustieteellinen Aikakausikirja 36: 14-21.

- 1975. Der Einfluss der Umwelt nördlicher Breitengrade auf die Qualität der Gemüse. Quality Plantarum 25: 43-56.

- \& HÅRDH, K. 1972. Effects of radiation, day-length and temperature on plant growth and quality: A preliminary report. Horticultural Research 12: 25-42.

-, Persson, A. R. \& OtTosson, L. 1977. Quality of vegetables cultivated at different latitudes in Scandinavia. Acta Agriculturae Scandinavica 27: 81-96.

HeInonen, M. 1990. Carotenoids and Provitamin A Activity of Carrot (Daucus carota L.) Cultivars. Journal of Agriculture and Food Chemistry 38: 609-612.

JOHANSSON, E. 1939. Bestämningar av askorbinsyrehalten hos frukt och fruktprodukter, vissa köksväxter samt vissa andra växtarter. Medd. Stat. Trädg. Förs. 4: 1-53.

Jokinen, R. \& TAHVonen, R. 1991. Salaatin viljely ja salaatin laatu. Maatalouden tutkimuskeskus, Tiedote 21/91. 178 p. [Cultivation of lettuce and quality of yield. Communications of Agricultural Research Centre of Finland, Jokioinen.].

Kansaneläkelaitos 1993. Ruoka-aineiden ravintoainesisältö. Livsmedlens näringsinnehåll. Nutrient composition of foods. 461 p. Helsinki.

Kaski, I. J., WeBster, G. L. \& KIRCH, E. R. 1944. Ascorbic acid content of tomatoes. Food Research 9: 386391.

KessLeR, W. 1939. The vitamin C content of German apple varieties and its dependence on habitat, light intensity, fertilizing, density of fruit hanging and storage. Gartenbauwissenschaft 13: 619-638.

Kleemola, P., Virtanen, M. J. \& Pietinen, P. 1994. Dietary survey of Finnish adults in 1992. Publications of the National Public Health Institute B/1994. Helsinki.

KuUsI, T. 1965. The most important quality criteria of some homegrown black-currant varieties. I. Ascorbic acid. Maataloustieteellinen Aikakausikirja 37: 264-281.

LAMBRECHT, H. \& SvensSON, V. 1950. Karotinhalt i morötter och dess beroende av olika faktorer. Agri Hortique Genetica 8: 74-108.

LEHTINEN, S. 1984. Avomaavihannesten lannoitus- ja kastelukokeet 1978-1983. Maatalouden tutkimuskeskus, Tiedote $21 / 84.62 \mathrm{p}$.

Levnedsmiddelstyrelsen 1990. Frugt og grønsager. Vurderet ud fra et helhedssyn. København. 90 p.

LINDEN, L. 1989. Pohjoisten ilmasto-olojen vaikutus kasvikunnan tuotteiden sisäiseen laatuun. Maa- ja metsätalousministeriö. Elintarviketutkimusprojekti. 4.3.1.7/ $1.60 \mathrm{p}$.

MCCollum, J. P. 1946. Effect of sunlight exposure on the quality constituents of tomato fruits. Proceedings of American Society of Horticultural Science 48: 413416. 
MAPSON, L. W. 1955. The biosynthesis of ascorbic acid. Vitamins Horm. 13: 71-100.

Maynard, D. N., Barker, A. V., Minotti, P. L. \& PeCK, N. H. 1976. Nitrate accumulation in vegetables. Advances in Agronomy 28: 71-118.

Mengel, K. 1972. Ernährung und Stoffwechsel der Pflanzen. VEB Gustav Fischer Verlag, Jena. 470 p.

Murneek, A. E., Maharg, L. \& Wittwer, S. H. 1954. Ascorbic acid (vitamin C) content of tomatoes and apples. University of Missouri. Agricultural Experiment Station. Research Bulletin 568: 1-24.

- \& WitTwer, S. H. 1948. Some factors affecting the ascorbic acid content of apples. Proceedings of American Society of Horticultural Science 51: 97-102.

NiLsson, F. 1969. Ascorbic acid in black currants. Lantbruk Högskolans Annmelingar 35: 43-59.

- \& HinTZE, S. 1952. Sort- och stamförsök med morötter 1948-50. Meddelanden av Statens Trädgårds Försök 75: $1-32$.

NILSsON, T. 1979. Avkastning, lagringsförmåga, kvalitet och kemisk sammansättning hos morot, vitkål och purjo vid konventionell och organisk gödsling. Instut av Trädgårds Vetenskap. Rapporter 7: 3-52.

NygaARD Sørensen, J. 1984. Dietary fibre and ascorbic acid in white cabbage as affected by fertilization. Acta Horticulturae 163: 221-230.

- 1988. Afgroedekvalitet. Frilandsgroensager. Statens planteavlsmoede 1988: 7-9.

Pettersson, B. D. 1982. Konventionell och biodynamisk odling. Jämförande försök mellan två odlingssystem 1971-1979. Nordisk forskningsring. Meddelanden 32.

Phan, C. T. \& Hsu, H. 1973. Physical and chemical changes occurring in the carrot root during growth. Canadian Journal of Plant Science 53: 629-634.

Plaami, S., SaAstamoinen, M. \& Kumpulainen, J. 1989. Effects of variety and environment on dietary fibre content of winter rye in Finland. Journal of Cereal Science 10: 209-215.

RoBINSON, W. B. 1949. The effect of sunlight on the ascorbic acid content of strawberries. Journal of Agricultural Research 78: 257-262.

RoSENFELD, H. J. 1975. Temperatureffekter på askorbinsyreinnhold i kruspersille (Petroselinum crispum Nym. var. crispum f. crispum). Meldelanden av Norges Landbruk högskole 54, 20: 1-12.

- 1978. Askorbinsyre. Kjemi, biokjemi, forekomst og funksjon i planter. Landbruk høgskole Meddelanden 57, 5: 1-28.

- 1979. Ascorbic acid in vegetables grown at different temperatures. Acta Horticulturae 93: 425-433.

SALO, T. 1992. Typpi- ja kloridilannoituksen vaikutus punajuurikkaan nitraattipitoisuuteen ja satoon. Maatalouden tutkimuskeskus, Tiedote 16/92. 43 p. [The effect of nitrogen and chloride fertilization on the nitrate content and yield of beetroot. Communications of Agricultural Research Centre of Jokioinen.].

SCHUPHAN, W. 1942. Die veränderungen der Vitamin Cund kalorischen vertstoff Gehalte bei deutschen Erdbeersorten unter dem Einfluss schönen und schlechten Wetters. Biochem. Z. 311: 151-162.

Simon, P. W., Peterson, C. E. \& Lindsay, R. C. 1982. Genotype, soil and climate effects on sensory and objective components of carrot flavor. Journal of American Society of Horticultural Science 107: 644-648.

- \& WolfF, X. Y. 1987. Carotenes in typical and dark orange carrots. Journal of Agricultural and Food Chemistry 35 : 1017-1022.

Somers, G. F., Hamner, K. C. \& Kelly, W. C. 1950. Further studies on the relationship between illumination and the ascorbic acid content of tomato fruits. Journal of Nutrition 40: 133-143.

TAKAlA, M., TAhVONEN, R. \& VuORINEN, M. 1988. Väkilannoitus ja 'biologiset' viljelymenetelmät perunan, porkkanan ja punajuurikkaan viljelyssä. Maatalouden tutkimuskeskus, Tiedote11/88. p. 1-36.

Varo, P., Laine, R., Veujalainen, K., Espo, A., WetterHOFF, A. \& KoIvistoINEN, P. 1984. Dietary fibre and available carbohydrates in Finnish vegetables and fruits. Journal of Agricultural Science in Finland 56: 49-59.

Vuorinen, M. \& TAKAla, M. 1987. Porkkanan ja punajuurikkaan sadetus, typpilannoitus ja kalkitus poutivalla hiekkamaalla. Maatalouden tutkimuskeskus, Tiedote 10/87. 30 p.

Manuscript received November 1993 


\title{
SELOSTUS
}

\section{Lannoituksen ja ympäristötekijöiden vaikutus kasvisten ravitsemukselliseen laatuun - yhteenveto Suomessa ja Skandinaviassa tehdyistä tutkimuksista}

\author{
Aino-MaiJa Evers
}

Maatalouden tutkimuskeskus

Avomaan puutarhatuotannossa edistetään kestävän kehityksen mukaista viljelytekniikkaa, jossa lannoitteiden ja torjunta-aineiden käyttöä tarkennetaan taloudellisista ja ekologisista syistä. Tässä tilanteessa on tärkeäå ymmärtää ne mekanismit, jotka määräävät tuotetun sadon laadun, jotta viljelytekniikalla opittaisiin vaikuttamaan sadon ravitsemukselliseen laatuun myönteisesti. Viime vuosikymmeninä Suomessa ja Skandinaviassa on julkaistu useita tutkimusraportteja mm. lannoituksen ja ympäristötekijöiden vaikutuksista ravitsemukselliseen laatuun. Tämän artikkelin tarkoitus on koota yhteen nämä tutkimukset ja selvittää voidaanko jo nähdä yleisiä trendejä ja mitkä seikat vaativat vielä lisätutkimusta.

Genotyypillä ja valon intensiteetillä on hyvin voimakas vaikutus kasvisten C-vitamiinipitoisuuteen. Optimaalisella typpilannoituksella lannoituksen merkitys on vähäinen, mutta liian suuri typpimäärä alentaa $\mathrm{C}$-vitamiinipitoisuutta luultavasti suurten lehtien varjostusvaikutuksen tai kuiva-ainepitoisuuden laskun vuoksi. Genotyyppi, kasvin kehitysvaihe, tehokas yhteyttäminen, voimakas kasvu ja suhteellisen korkea lämpötila lisäävät porkkanalla karoteenipitoisuutta. Sensijaan lannoituksen vaikutukset karoteeni- pitoisuuteen ovat olleet ristiriitaisia eri tutkimuksissa, joten lisätutkimuksia tarvittaisiin tästä asiasta, varsinkin kun kasvikset ovat erittäin tärkeä karoteenin lähde ruokavaliossamme.

Kasvikset ovat myös B-vitamiinien tärkeä lähde, mutta ainoatakaan tutkimusta lannoituksen tai viljelytekniikan vaikutuksista kasvisten B-vitamiinipitoisuuuksiin ei löytynyt. Lannoituksella on vain vähäinen vaikutus kasvisten sokeripitoisuuteen. Lannoituksen vaikutuksia kasvisten kuitupitoisuuteen on tutkittu văhän, mutta alustavat tutkimustulokset ovat lupaavia ja jatkotutkimuksia tarvittaisiin.

Kasvisten nitraattipitoisuuksia on tutkittu paljon ja siihen vaikuttavat tekijät tunnetaan hyvin. Nouseva typpilannoitus, genotyyppi, alhainen valon intensiteetti, alhainen lämpötila ja kuivuus lisäävät nitraatin määrảä kasviksissa. Suomessa ja Skandinaviassa kasvatettujen kasvisten nitraattipitoisuudet ovat olleet lannoituskokeissa alhaiset, ainoastaan kasvihuoneessa kasvatettujen salaattien nitraattipitoisuudet ovat olleet korkeat ja tämä vaatisi lisätutkimuksia. 